\title{
NUCLEAR ZIRCONIUM - THE BASIS OF ALLOYS WITH IMPROVED NEUTRON-PHYSICAL, RADIATION, AND CORROSION PROPERTIES
}

\author{
A.P. Mukhachev, M.M. Pylypenko ${ }^{1}$, O.A. Kharytonova ${ }^{2}$ \\ Center for Chemical Technology AINU, Kamianske, Ukraine; \\ ${ }^{1}$ National Science Center “Kharkov Institute of Physics and Technology”, Kharkiv, Ukraine; \\ ${ }^{2}$ Dneprovsky State Technical University, Kamianske Ukraine \\ E-mail:eah@ukr.net
}

The paper provides a review of industrial technologies for the production of nuclear zirconium. Their advantages and disadvantages have been shown, a comparative analysis of the quality of zirconium and hafnium salts has been given. Zirconium with a purity of $99.95 \%$, is on a par with the quality of the iodide metal, with a hafnium content of less than $0.005 \%$, was obtained from zirconium tetrafluoride (TFZ) by electrolysis and method of salt recovery with calcium.

\section{INTRODUCTION}

Zirconium alloys of nuclear purity (NP) are indispensable structural materials for producing products that are operated in the core as part of nuclear fuel (NF) of water-cooled reactors. 35 tof zirconium alloy products are used in the NF of the WCPR-1000 reactor (water-cooled power reactor). The needs of all Ukrainian NPPs for rolled zirconium are 130 tons per year. It is supplied as a part of NF from the Russian Federation (licensed) and the United States (experimental-industrial operation). Soda-extraction technology for the processing of zircon with the production of nuclear-pure salts of zirconium, $\mathrm{K}_{2} \mathrm{ZrF}_{6}$ and $\mathrm{ZrF}_{4}$ was developed and introduced in Ukraine in 1978-1991. This made it possible to obtain zirconium with a purity of $99.95 \%$ and with a hafnium content of less than $0.005 \%$ by electrolysis and method of salt recovery with calcium. Based on zirconium, serial alloys with 1 and $2.5 \%$ niobium were obtained and serial products were manufactured for testing on WCPR-440. Radiation and corrosion resistance of products is fully consistent with operating standards. Decree of the President of Ukraine No104/2019 set the task for the production of domestic NF which should be created on the basis of Ukrainian components, its own raw materials, using modern technologies. To implement the Decree, it is necessary to analyze existing technologies for the production of zirconium, summarize the results of experimental-industrial tests conducted in Ukraine, to determine the disadvantages and advantages of each technology, taking into account economic, environmental requirements and product quality.

\section{ANALYSIS OF INDUSTRIAL TECHNOLOGIES FOR THE ZIRCONIUM PRODUCTION}

The industrial scheme of zircon processing in the USSR by the methods of chlorination and extraction separation of $\mathrm{Zr}$ and $\mathrm{Hf}$ was first implemented in Ukraine at the mining and metallurgical plant in Volnogorsk. This production was created to obtain zirconium and hafnium used for military purposes. The hafnium-nickel alloy was used in the production of turbines of the SU-27 fighter. Zirconium, in the form of finely divided pyrophoric powder, was used in ammunition.

The high purity of zirconium oxide made it possible to obtain zirconium chloride of the following composition, $\%$ : Hf $-0.16, \mathrm{Fe}-0.05, \mathrm{Si}-0.014, \mathrm{Ti}-0.001, \mathrm{Mn} \leq 0.005$, $\mathrm{Ca}-0.001, \mathrm{Cu}-0.001, \mathrm{~Pb} \leq 0.001, \mathrm{~B} \leq 0.00003$, $\mathrm{Cd} \leq 0.0001, \mathrm{Mg}-0.006, \mathrm{Sn}-0.012, \mathrm{Cr}-0.025$.

Chlorination of zirconium oxide was carried out in a $\mathrm{NaCl}-\mathrm{KCl}$ melt at a temperature of $600 \ldots 750{ }^{\circ} \mathrm{C}$.

To produce zirconium, scientists of SC "VNIINM" (Stock Company "A.A. Bochvar. High-technology Research Institute of Inorganic Materials") developed and manufactured an experimental-industrial installation of the combined "Topol" type [1]. The reduction of zirconium chloride with magnesium, the discharge of slag and vacuum cleaning of the sponge were carried out without intermediate recovery of the reaction crucible. This ensured high purity of the metal and good performance of the installation.

The separation of $\mathrm{Zr}$ and $\mathrm{Hf}$ was carried out during the extraction with methyl isobutyl ketone in a chloriderhodanide medium. Sump mixers were protected against corrosion by rubber. Due to the lack of marketing facilities, zirconium and hafnium oxides were put into the State Reserve. The main characteristics of the "Topol" installation are given in Table.

\begin{tabular}{|c|c|c|}
\hline No & Technological parameters & Indicators \\
\hline 1 & $\begin{array}{c}\text { Performance, } \\
\text { kg/cycle } \\
\text { t/year }\end{array}$ & $\begin{array}{c}500.0 \\
50.0\end{array}$ \\
\hline 2 & Cycle time & 70.0 \\
\hline 3 & $\begin{array}{c}\text { Vacuum temperature } \\
\text { separation, }{ }^{\circ} \mathrm{C}\end{array}$ & 960 \\
\hline 4 & Residual pressure, $\mathrm{mm} \mathrm{Hg}$ & 1.5 \\
\hline 5 & Unit material & X18H10T \\
\hline 6 & Crucible material & Steel \\
& ЭИ 852 \\
\hline 7 & $\begin{array}{c}\varnothing, \text { mm } \\
\text { height, mm }\end{array}$ & 700 \\
& $\quad 1200$ \\
\hline
\end{tabular}

Zirconium contained impurities, $\%$ : $\mathrm{O}-0.12, \mathrm{~N}-$ $0.006, \mathrm{C}-0.002, \mathrm{Fe}-0.24, \mathrm{Ni}-0.008, \mathrm{Hf}-0.016$, $\mathrm{Cr}-0.02, \mathrm{Al}-0.002, \mathrm{Ti}-0.03, \mathrm{Cu}-0.001, \mathrm{Mn}-$ 0.002 . 
Alloys with 1 and $2.5 \% \mathrm{Nb}$ and an experimental batch of products were produced from the $\mathrm{Zr}$ sponge: tube - Ø9.15..7.7 mm, bar - Ø $12 \mathrm{~mm}$, sheet $80 \times 250 \times 1.6 \mathrm{~mm}$, metal had good mechanical properties.

The estimated cost of $\mathrm{Zr}$ in experimental-industrial production was 10.1 rubles for $1 \mathrm{~kg}$. In 1991, Ukraine stopped researching the magnesium-thermal process.

Chloride-magnesium sponge technology has not changed in almost 75 years; it continues to work in the
USA at Westinghouse. Its Western Zirconium plant in Oregon produces $1.400 \mathrm{t}$ of pipe billets, using the technology shown in Fig. 1. The quality of the sponge complies with ASTM B349-80. The content of $\mathrm{Zr}$ in the sponge is $99.7 \%$, hafnium in $\mathrm{Zr}$ is at the level of $0.008 \%, \mathrm{Zr}$ in hafnium is up to $4.0 \%$. The sponge is doped with a total of Ni-Cr-Fe metals up to $0.18 \ldots 0.38 \%$ and tin $1.2 \ldots 1.7 \%$ to produce the Zircaloy-2 and 4 and Zirlo alloys.

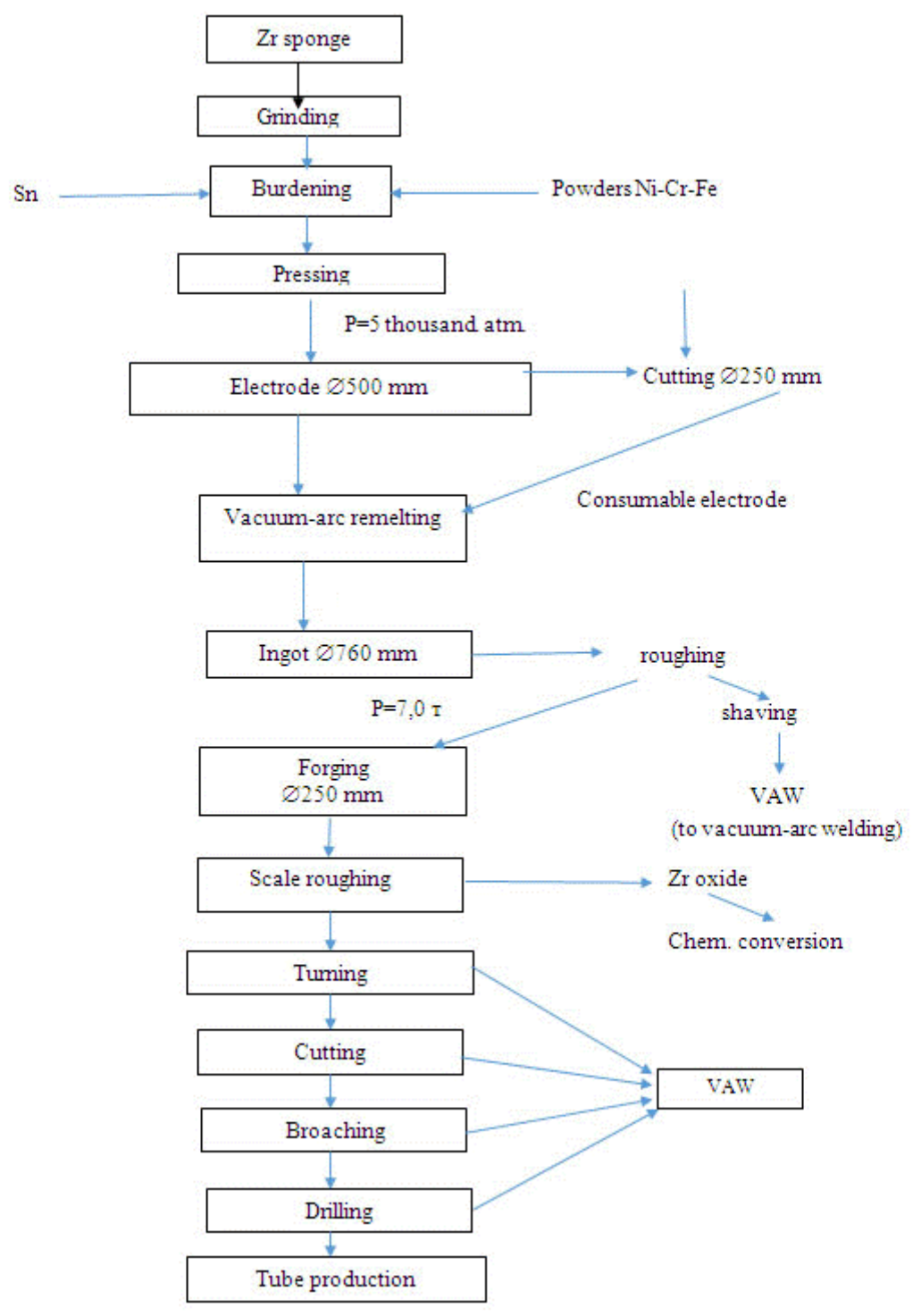

Fig. 1. Technological scheme for the production of pipe billets

The advantages of the technology are the following:

- the absence of oxidized metal turns, which excludes iodide redistribution;

- cutting the $\varnothing 500 \mathrm{~mm}$ electrode with water;

- high quality of alloy ingot after 3-fold vacuum-arc remelting;

- high level of mechanization and automation.

The disadvantage of the technology is the need for the disposal of liquid effluents containing calcium chloride.

Zircaloy-2 alloy products cannot be used in WWER1000 reactors due to low corrosion resistance. Therefore, Westinghouse uses a Zirlo alloy with improved corrosion properties in an experimental NF.
This NF is being tested in Ukraine. They will be completed in 2022.

Let's consider the industrial scheme for producing zirconium by the electrolysis of molten salts. For the first time, the possibility of producing zirconium of nuclear purity by this method was reported at the 1956 Geneva Conference on the Peaceful Use of Nuclear Energy by scientists at the SC "VNIINM". In 1964, this method was implemented on open electrolyzers, with the production of a powder oxidized by oxygen and nitrogen. To produce a ductile metal, $\mathrm{Zr}$ powder was subjected to iodide refining to produce crystalline bars of Ø $20 \mathrm{~mm}$.

The amount of $\mathrm{Zr}$ and $\mathrm{Hf}$ salts was produced by 
sintering zircon with potassium fluorosilicate $\mathrm{K}_{2} \mathrm{SiF}_{6}$ at $800{ }^{\circ} \mathrm{C}$. Fractional crystallization of $\mathrm{K}_{2} \mathrm{ZrF}_{6}$ and $\mathrm{K}_{2} \mathrm{HfF}_{6}$ in 11 stages made it possible to obtain a salt with a high hafnium content of $0.05 \%$. The zirconium extraction was at the level of $70 \%$. Along the way, a mixture of $\mathrm{K}_{2} \mathrm{HfF}_{6}$ with $\mathrm{K}_{2} \mathrm{ZrF}_{6}$ with a hafnium content of $6 \ldots 10 \%$ was obtained. This concentrate was processed in Ukraine according to the extraction scheme to obtain $\mathrm{ZrF}_{4}$.

In the process of electrolysis from $\mathrm{K}_{2} \mathrm{ZrF}_{6}$ in Russian Federation, $\mathrm{Zr}$ powder with a hafnium content of $0.035 \%$ was obtained. This exceeded ASTM requirements (less than $0.01 \%$ ) and led to an increase in uranium consumption.

At the end of the $60 \mathrm{~s}$ SC "VNIINM" scientists developed a vacuum-sealed $10 \mathrm{kA}$ electrolyzer. It made possible to obtain $\mathrm{Zr}$ powder with a low content of gas impurities; however, up to $20 \%$ of $\mathrm{Zr}$ powder was oxidized during the discharge of the electrolyte, which preserved the iodide refining process. The cathode product (CP) was processed using ammonium carbonate, resulting in the formation of chloride effluents that could not be processed. They were buried together with liquid gas treatment effluents into the underground horizon to a depth of $1 \mathrm{~km}$. Anode gases containing chlorine and freons were purified from chlorine with a $20 \%$ solution of lime milk. Freons were discharged into the atmosphere. The technological scheme for the production of zirconium by electrolysis is given in [2].

After the introduction of vacuum-sealed electrolyzers, the amount of iodide conversion was halved. The government decided to build a second industrial base for the production of zirconium in 1971 . The new production was designed for $2000 \mathrm{t}$ of metal per year. For the electrolysis process, it was plan-ned to use electrolyzers at $20 \mathrm{kA}$. The non-chlorine method for the production of $\mathrm{Zr}$ and $\mathrm{Hf}$ salts fundamentally solved environmental and economic problems and made it possible to obtain $\mathrm{Zr}$ salt with $\mathrm{Hf}$ content of less than $0.005 \%$. The planned technology for the production of pipe billets (PB) did not fundamentally differ from the technology adopted in the USA.

Let's consider the technological advantages of the electrolysis process over the method of salt recovery with magnesium:

1. The electrolysis process is semi-continuous, it occurs at a temperature of $750{ }^{\circ} \mathrm{C}$ under the influence of electric current, a clean and inexpensive reagent. It successfully replaces magnesium.

2. The skull protection of the electrolyzer elements and carbonate processing of the $\mathrm{CP}$ maintain the quality of the powder.

3. $\mathrm{Zr}$ powder is more technological than a sponge. It is evenly mixed with alloying powders, pressed in vacuum at a lower pressure than a sponge.

4. The starting salts $\mathrm{K}_{2} \mathrm{ZrF}_{6}$ and $\mathrm{KCl}$ are less hygroscopic than $\mathrm{ZrCl}_{4}$. They are constantly introduced into the electrolysis process.

5. Chlorine and freons in the composition of the anode gas are valuable chemical products. They reduce the cost of $\mathrm{Zr}$.

6 . The electrolysis process is more automated.
Along with the advantages, the entire technology of zircon processing in the Russian Federation has several disadvantages [3].

1. The process of leaching zircon has an efficiency of not more than $90 \%$. The extraction of $\mathrm{Zr}$ in $\mathrm{K}_{2} \mathrm{ZrF}_{6}$ at 11 stages of fractional crystallization did not exceed $70 \%$.

2. The content of hafnium in the zirconium salt exceeds $0.01 \%$. This reduces the nuclear-physical properties of $\mathrm{Zr}$ alloys and increases the consumption of uranium in NF up to $4 \%$. Silicon oxide in zircon is not extracted.

3. A by-product of the crystallization process is $6 . .10 \%$ hafnium concentrate, which contained zirconium and required processing.

4. Chloride effluents are not processed.

5. Freons negatively affect the ozone layer of the atmosphere.

6. The use of $\mathrm{K}_{2} \mathrm{ZrF}_{6}$ with a $\mathrm{Zr}$ content of $\mathrm{Zr}-32 \%$ and $40 \% \mathrm{KF}$ reduces the current efficiency, process productivity, and degrades the quality of $\mathrm{Zr}$ powder.

7. Oxidized turns of $\mathrm{Zr}$ must be purified from $\mathrm{O}, \mathrm{N}$ by iodide refining.

8. The technology for producing $\mathrm{Zr}$ alloy products gives a wide variety of metal revolutions. The processing of turns is very expensive.

To eliminate the shortcomings of the electrolysis process an experimental-industrial site was created on the basis of a $10 \mathrm{kA}$ vacuum-sealed electrolyzer at the Pridneprovsky Chemical Plant (PCP) in 1977. For more efficient processing of $\mathrm{CP}$ and anode gas, new technical solutions were adopted, which are shown in Fig. 2.

Industrial tests of the $\mathrm{K}_{2} \mathrm{ZrF}_{6}$ and $\mathrm{Zr}_{2} \mathrm{~F}_{4}$ salts obtained after the extraction separation of $\mathrm{Zr}$ and $\mathrm{Hf}$ showed quality advantages over $\mathrm{K}_{2} \mathrm{ZrF}_{6}$ obtained by fractional crystallization, primarily in the content of $\mathrm{Hf}$ and $\mathrm{Si}$.

Replacing $\mathrm{K}_{2} \mathrm{ZrF}_{6}$ with $\mathrm{ZrF}_{4}$ (TFZ) containing $54 \%$ $\mathrm{Zr}$ can increase the efficiency of the electrolysis process by $30 \%$ [4].

Unfortunately, low-Hf $\mathrm{Zr}$ powder has not passed the full cycle of pre-reactor and reactor tests. It has been recognized as the appropriate serial product for the analysis of chemical and gran composition.

Work on the utilization of freons and chlorine from the anode gas during the opening of zircon gave a good result [5], however, the presence of chlorine and fluorine in $\mathrm{Zr}$ compounds required their purification. Processing freons in the synthesis of organic compounds has shown their effectiveness. These experiments were carried out at the Institute of Physical Chemistry of NASU in 2000-2008 [6]. Unresolved environmental problems in the technology of processing electrolysis products have determined the choice of calcium-thermal technology for producing $\mathrm{Zr}$. Previously, this technology was developed in Canada, but $\mathrm{ZrF}_{4}$ of the required purity could not be obtained due to the presence of oxygen. The use of ceramic oxide materials in a crucible caused the oxidation of $\mathrm{Zr}$ at a temperature of $220^{\circ} \mathrm{C}$. The use of sublimation cleaning TFZ on the sublimator with internal heater, developed by scientists of the Tomsk Polytechnic Institute (RF), reduced the $\mathrm{O}_{2}$ content to $0.05 \%$. 


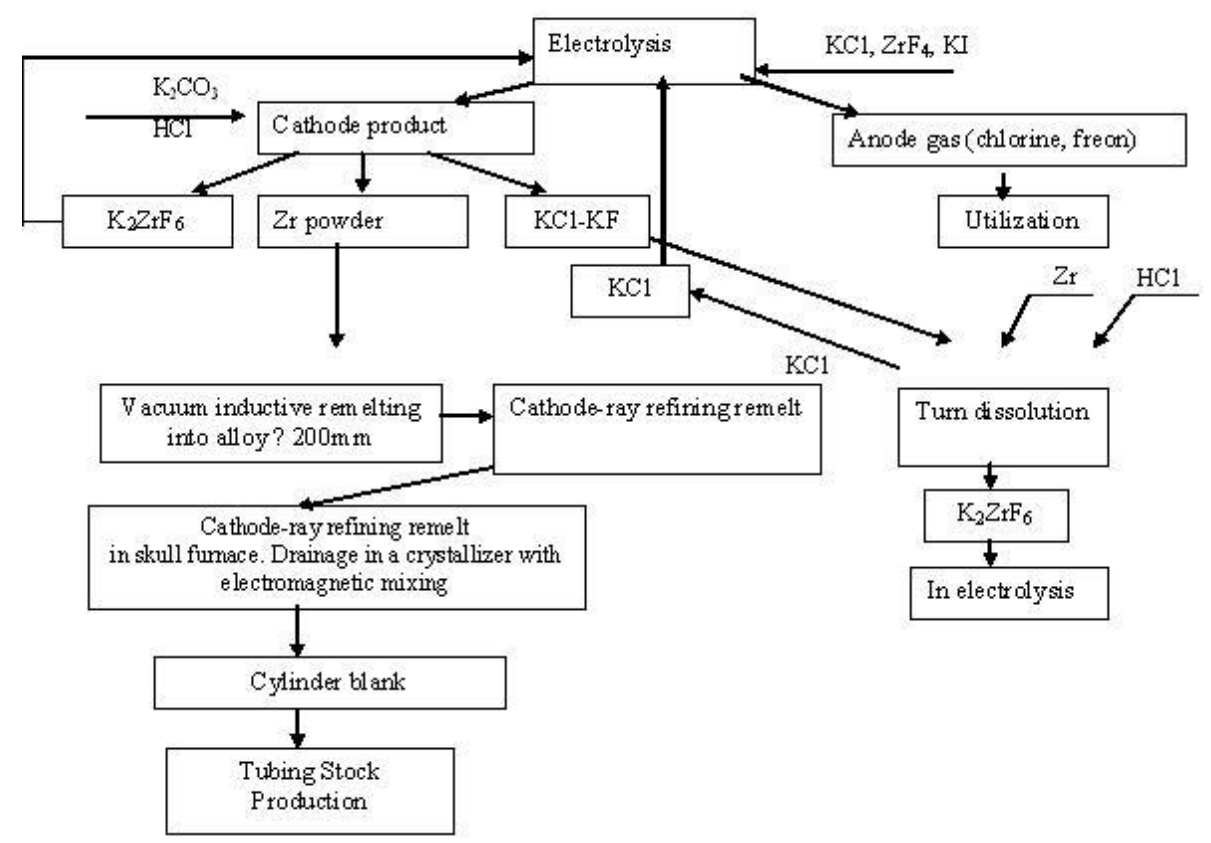

Fig. 2. The technological scheme of obtaining Zr powder in the electrolysis process (Ukraine)

Reduction of $\mathrm{ZrF}_{4}$ grade "chp" (chemical purity) with calcium in "cold" copper crucibles, cooled by water, preserved the quality of $\mathrm{Zr}$. Test $\mathrm{Zr}-\mathrm{Nb}$ alloy ingots were refined on the electron beam unit UE-182, developed at the Institute of Electric Welding named after Paton E.O. It was decided to create in Ukraine an experimental-industrial production of calcium-thermal zirconium (KTZ) with a volume of $200 \mathrm{t}$ per year in 1976. The first $\approx 100 \mathrm{t}$ of KTZ-110 alloy ingots were transferred to JSC "Chepetsky Mechanical Plant" in the Russian Federation. During 1978-2003 technological tests of equipment were carried out, serial products were obtained in the form of a pipe and a sheet of alloys KTZ-110 and KTZ-125 in the Russian Federation. They successfully passed reactor tests in the Russian Federation on WWER-440 and RBMK. Zr production capacity was increased to $250 \mathrm{t} \mathrm{ZrF}_{4}$ per year.

The improvement of $\mathrm{Zr}$ production technologies was carried out with the participation of leading institutes in the field of radiation materials science. Products on vacuum-arc and electron-beam technologies, with and without forging of ingots, were identical. Scientists of State Pipe Institute proposed a new technology for producing tubes from the KTZ-110 alloy [7]. Comparative tests of products obtained from various pipe billets conducted at the NSC KIPT have confirmed the potential of the new technology. Pre-reactor tests have confirmed their compliance with the geometry and properties of serial products obtained by electrolysis technology. The test results can be used to draw up regulatory documents on the rationale for the use of products made of alloys KTZ-110 and KTZ-125 in the core of WWER reactors.

Advantages of the Ukrainian technology of zircon processing to produce $\mathrm{PB}$ and pipes from zirconium alloys of nuclear purity are:

1. Full leaching of zircon with soda and its use in the production of sodium nitrate.

2. The possibility of obtaining $\mathrm{SiO}_{2}$ in the form of white soot for tire production.

3. The use of the centrifugal method for the separation of hard-to-filter precipitate of silicon compounds and $\mathrm{Zr}$ and Hf solutions.

4. Deep extraction separation of $\mathrm{Zr}$ and $\mathrm{Hf}$ in a centrifugal field, in a nitric acid medium, regeneration of $\mathrm{HNO}_{3}$.

5. Obtaining salts of $\mathrm{Zr}$ and $\mathrm{Hf}$ with a purity of $99.9 \%$.

6. Sublimation removal of gas impurities from $\mathrm{ZrF}_{4}$.

7. Recovery of $\mathrm{ZrF}_{4}$ with high purity calcium to produce an alloy ingot.

8. Electron beam refining of ingots of KTZ-110 and 125 alloys with metal cleaning from slag and volatile impurities.

9. Obtaining a fine-grained alloy structure by the electron beam skull melting method $\mathrm{Zr}$, with obtaining a tube billet (TB) of the required geometry and quality.

10 . The use of corrosion-resistant materials, fluoroplastic, and steels of the nickel-molybdenum alloys, made it possible to protect $\mathrm{Zr}$ from corrosion.

11. The development of modern high-performance equipment based on vacuum technology has allowed metallurgical processes to be carried out at temperatures above $2200{ }^{\circ} \mathrm{C}$.

The electron beam technology of refining and remelting an alloy with $\mathrm{Zr}$ discharge into crystals and intake with electromagnetic mixing of refractory metals showed the possibility of additional purification of zirconium. In the process of testing the EBM and EBI processes, $\approx 500$ t of the KTZ-110 alloy were obtained, which corresponds in chemical composition to the serial alloy E110. A distinctive feature of the alloy was its oxygen content at the level of $0.10 \ldots 0.14 \%$. SC "VNIINM" (RF) and NSC KIPT substantiated the need to increase the oxygen content in order to increase the strength of the metal, which improved the operational properties of the products. This conclusion was confirmed during pre-reactor tests. All tests carried out 
before 1991 were conducted in the Russian Federation at research stands and facilities that were not available in Ukraine. Cooperation relations after 1991 were limited to the supply of $\mathrm{ZrF}_{4}$. State programs for the creation of NFCs since 2000 allowed to complete the development of domestic technology for the production of billets and pipe products, however, all further studies were discontinued.

The decisions taken by the Ministry on the creation of chloride-magnesium-thermal technology (R\&D stage) for the production of $\mathrm{Zr}$ sponge under conditions of funding shortages, without taking into account the regulatory timelines for the development and implementation of new processes, have not been implemented. The implementation period of this technology requires at least 20 years. The capacities of the SSPE "Zirconium" were removed from operation, and the production of $\mathrm{Zr}$ and $\mathrm{Hf}$ was discontinued.

Presidential Decree No104/2019 again set the task of creating domestic NF. The issue of acquiring industrial technologies for the production of zirconium (magnesium-thermal in the United States and electrolytic in the Russian Federation) is unlikely, since the United States and the Russian Federation divided the Ukrainian nuclear fuel market. They are not interested in creating a competitor partner.

The results of experimental-industrial tests of new technological processes from zircon leaching to sublimation purification of $\mathrm{ZrF}_{4}$, electrochemical and calcium thermal reduction to produce reactor-grade zirconium by electron beam and vacuum induction refining methods have been patented. Not a single country in the world has brought to the experimentalindustrial introduction three main technologies: magnesium-thermal, electrolytic and calcium-thermal. Ukraine has managed to do this.

The issues of product quality were practically resolved during the production of experimental lot of pipes, rods and sheets. In order to certify products in the system (Germany) universally recognized in the world, it is necessary to conduct licensed tests on certified equipment that exists only in the form of prototypes (vacuum-induction furnace, EBM), and create a quality control system for all types of products.

In addition to calcium thermal technology, Ukraine has good test results for $\mathrm{Zr}$ salts during electrolysis, certified in the Russian Federation.

To meet the needs of the country's nuclear power plants, it is enough to install a series of 6 electrolyzers at $10 \mathrm{kA}$, which will operate on $\mathrm{ZrF}_{4}$ and will ensure the production of $200 \mathrm{t}$ of powder per year. Ecological problems of the electrolysis process will be solved taking into account the developments of the institutes of NASU. The final part of the technology for the production of TB from $\mathrm{Zr}$ alloy based on electron beam technologies was developed by Ukrainian scientists and does not require the purchase of import licenses and equipment.

The chemical technology of zircon processing developed in Ukraine has undeniable competitive advantages in comparison with the USA, the Russian Federation, and France, which ensures competitive profitability of the metal and high quality products.
The choice between the old technology for obtaining $\mathrm{TB}$, using the processes of electron beam melting and forging, and the new processes of electron beam remelting and casting, can be made on the basis of calculations of capital costs. Production of technological equipment can be organized in Ukraine. The pipe conversion should be organized on the basis of licensed rolling equipment manufactured in Germany. Pipes must be certified and tested on WWER-1000.

The engineering-and-economical performances of the electrolysis process based on the $\mathrm{ZrF}_{4}-\mathrm{KCl}-\mathrm{KF}$ electrolyte obtained on the $20 \mathrm{kA}$ electrolyzer [4] clearly exceed similar parameters of the electrolysis process based on the $\mathrm{K}_{2} \mathrm{ZrF}_{6}-\mathrm{KCl}-\mathrm{KF}$ electrolyte operating in the Russian Federation. The world's leading companies, Westinghouse (USA) and TVEL (Russian Federation), are developing new complex alloyed Zirlo and E635 alloys, which should provide a NF service life of up to 5 years and a nuclear burnout depth of up to 70 (MW $\cdot$ day) $/ \mathrm{kgU}$. On the basis of Ukrainian zirconium, the service properties of these alloys must be competitive.

A possible technological scheme for obtaining TB from a zirconium alloy, taking into account the results of experimental-industrial tests, is given in [7].

\section{CONCLUSION}

All industrial technologies for producing zirconium for NF engineering, operating in the USA, the Russian Federation, and France, ensure its quality at the level of $99.7 \ldots 99.8 \%$ with a hafnium content of $(0.008 \pm 0.001) \%$. Zirconium-based alloys have good mechanical, corrosive and radiation properties. This allows you to get products of any geometry. Doping of zirconium with $\mathrm{Ni}, \mathrm{Cr}, \mathrm{Fe}$, and $\mathrm{Sn}$ (USA), niobium (RF and Ukraine) ensures high mechanical properties and radiation resistance of products in the reactor core with a neutron fluence of up to $1 \cdot 10^{22}$ neutr. $/ \mathrm{cm}^{2}$, within 4 years and nuclear fuel burnup up to 50 (MW·day) $/ \mathrm{kgU}$.

$\mathrm{Zr}$ alloys doping with oxygen is normatively established only by Ukraine at the level of $0.10 \ldots 0.14 \%$, which increases the strength of zirconium during operation, without worsening the ductility, which is necessary for the primary deformation of $\mathrm{Zr}$. The content of $\mathrm{O}_{2}$ in alloys of the Zircaloy type is not limited, it is the right of the customer. The content of $\mathrm{O}_{2}$ in E110 and E125 in the Russian Federation is set at $\leq 0.10 \%$, which objectively increases the irradiation creep of products during operation. The nuclearphysical properties of zirconium depend on the content of hafnium and metallic impurities. The best quality parameters for the purity of salts of $99.95 \% \mathrm{Zr}$ and $\leq 0.005 \%$ Hf are ensured by extraction separation of $\mathrm{Zr}$ and Hf using tributyl phosphate in centrifugal extractors and electron beam refining technology of KTZ-110 and KTZ-125 alloys (Ukraine).

Calcium-thermal technology Zr (Ukraine) makes it possible to obtain ingots of $\mathrm{Zr}$ alloys with niobium with a purity of $99.9 \%$ and a hafnium content of less than $0.005 \%$. Electrolytic technology using $\mathrm{ZrF}_{4}$ (Ukraine) can be competitive, maintaining the quality of the metal at a level of $\geq 99.9 \%$, without violating environmental requirements. 
In technologies of the Russian Federation and the USA, vacuum-arc remelting is used. It allows get ingots with a fine-grained structure, which sets off the negative effect of the high content of impurities. The quality of alloys E110 and E125 is increased by alloying Zr powder, with a more expensive, iodide metal. Its content in the mixture before melting can reach $30 \%$, which increases the cost of products.

Environmental parameters of magnesium-thermal (USA) and electrolysis technologies (RF) are still not in compliance with environmental standards, since chloride effluents are not processed. In calculating the cost of metal, environmental damage is still not taken into account. Ukrainian technology of complex zircon processing is waste-free, utilizes all reagents, avoiding the discharge of liquid and solid waste.

The use of highly efficient technologies and domestic raw materials and equipment allows us to obtain $\mathrm{Zr}$ with a purity of $99.95 \%$, with a minimum content of impurities that affect the nuclear-physical properties of the products.

The concurrent production of hafnium, with a purity of $99.95 \%$, makes it possible to reduce the production cost of $\mathrm{Zr}$ and to obtain a highly efficient absorbing material for reactor protection control systems. Its advantages are confirmed by tests on reactors SM-2, Mir, and Bor-60 [8]. Thus, a comparison of technological, environmental, engineering-andeconomic parameters of industrial technologies and $\mathrm{Zr}$ quality, clearly indicates the potential competitive advantages of Ukrainian technologies for producing nuclear-grade zirconium. This paves the way for further R\&D to improve the finishing technologies to obtain a tube, sheet, rod and wire that meets ASTM requirements. Conducting reactor tests of products on WWER-1000 made of zirconium allows us to obtain results to substantiate the use of Ukrainian zirconium in nuclear power engineering.

\section{REFERENCES}

1. Е.Н. Обломеев, Ю.Г. Зинченко, А.В. Конов и др. Опытно-промышленная проверка технологии и аппаратуры для получения циркония хлоридномагниетермическим методом // Tезисы докладов V
Конференции по гидрометаллургии и металлургии цчиркония и гафния, г. Днепродзержинск. 1980, c. $139-140$.

2. A.P. Mukhachov, V.G. Nefedov, O.A. Kharytonova. Electrode processes in electrolysis of zirconium at production of plastic zirconium for nuclear energy // Вопросы атомной науки и техники. 2019, №2(120), c. 111-115.

3. А.М. Аржаткин, С.В. Головин, В.Д. Федоров и др. Технология и оборудование для получения технических кристаллов фторцирконата калия при вскрытии цирконового концентрата // Сборник материалов VI Отраслевой конференции по гидрометаллургии и металлургии ииркония $u$ гафния, г. Днепродзержинск. 1986, с. 24-26.

4. А.Н. Огарев, И.Н. Галкин, А.Ф. Неделеев и др. Внедрение и промышленное освоение герметичных электролизеров на 20 кА // Сборник материалов VI Отраслевой конференции по гидрометаллургии и металлургии циркония $u$ гафния, г. Днепродзержинск. 1986, с. 156-157.

5. В.Д. Федоров, П.М. Верховых, А.М. Аржаткин. Разработка процесса утилизации анодных газов для вскрытия цирконового концентрата и переработки металлических отходов в расплаве отработанного электролита // Тезисы докладов V Конференции по гидрометаллургии и металлургии ичикония и гафния, г. Днепродзержинск. 1980, с. 86-87.

6. В.Е. Титов, А.М. Мишура, В.Г. Кошечко. Совместная электрохимическая конверсия фреонов С-2С диоксидами углерода и серы // Bопросы химии и химической технологии. 2011, №4(2), с. 224-226.

7. В.С. Вахрушева, Ю.М. Правдин, Т.А. Деркач, Г.Д. Сухомлин. Разработка технологических схем и изготовление опытных партий труб-оболочек ТВЭЛ из сплава $\mathrm{Zr} / \mathrm{Nb}$ в Украине // Сб. докладов Международной конференции «Атомная энергетика на пороге XXI века», 8-10 июня 2000 г. Электросталь (Россия). 2000, с. 169-175.

8. В.Д. Рисованый, Е.П. Клочков, .В. Пономаренко. Гафний в ядерной технике: Монография. Димитровград, 1993, 141 с.

Article received 11.12.2019

\section{ЦИРКОНИЙ ЯДЕРНОЙ ЧИСТОТЫ - ОСНОВА СПЛАВОВ С УЛУЧШЕННЫМИ НЕЙТРОННО-ФИЗИЧЕСКИМИ, РАДИАЦИОННЫМИ И КОРРОЗИОННЫМИ СВОЙСТВАМИ}

\section{А.П. Мухачев, Н.Н. Пилипенко, Е.А. Харитонова}

Приведен обзор промышленных технологий производства циркония ядерной чистоты. Показаны их достоинства и недостатки, а также сравнительный анализ качества солей циркония и гафния. Цирконий чистотой 99,95\%, не уступающий качеству йодидного металла, с содержанием гафния менее $0,005 \%$ был получен из тетрафторида циркония (ТФЦ) методами электролиза и кальциетермии.

\section{ЦИРКОНІЙ ЯДЕРНОЇ ЧИСТОТИ - ОСНОВА СПЛАВІВ 3 ПОЛІПШЕНИМИ НЕЙТРОННО-ФІЗИЧНИМИ, РАДІАЦІЙНИМИ ТА КОРОЗІЙНИМИ ВЛАСТИВОСТЯМИ}

\section{А.П. Мухачов, М.М. Пилипенко, О.А. Харитонова}

Наведено огляд промислових технологій виробництва цирконію ядерної чистоти. Показані їх достоїнства і недоліки, а також порівняльний аналіз якості солей цирконію та гафнію. Цирконій чистотою 99,95\%, що не поступається якістю йодидному металу, з вмістом гафнію менш 0,005\% був отриманий 3 тетрафториду цирконію (ТФЦ) методами електролізу і кальцієтермії. 